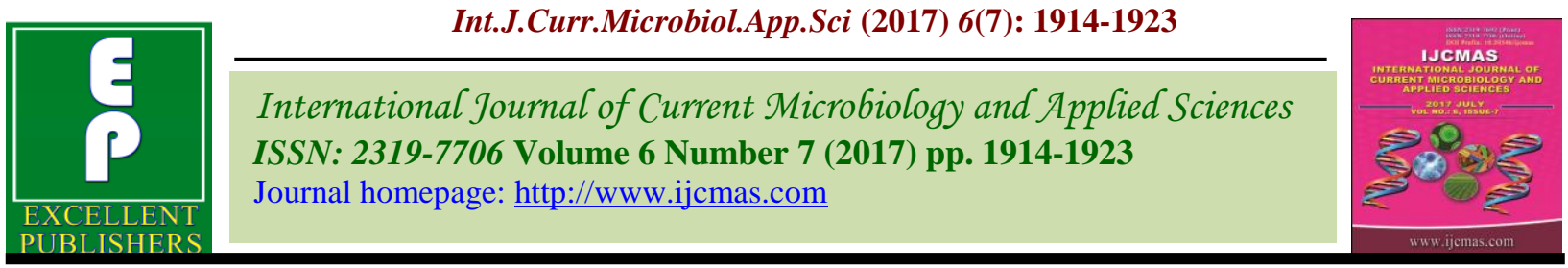

Original Research Article

https://doi.org/10.20546/ijcmas.2017.607.228

\title{
Genetic Parameters of Variability and Path Analysis in Wheat under Timely and Late Sown Conditions
}

\author{
Neeru", I.S. Panwar and Vikram Singh \\ Department of Genetics and Plant Breeding, CCS Haryana Agricultural University, \\ Hisar - 125 004, Haryana, India \\ *Corresponding author
}

\section{A B S T R A C T}

\begin{tabular}{|l|}
\hline Ke y w o r d s \\
Genetic \\
variability, \\
Correlation \\
coefficient, \\
Heritability, \\
Genetic advance, \\
Wheat. \\
\hline Article Info \\
\hline $\begin{array}{l}\text { Accepted: } \\
\text { 21 June } 2017 \\
\text { Available Online: } \\
\text { 10 July } 2017\end{array}$ \\
\hline
\end{tabular}

An experiment was conducted to determine the genetic variability, heritability, genetic advance and character association for yield and its component traits in 60 wheat genotypes under timely and late sown conditions. Significant genotypic differences were observed for all the traits in both environments. The moderate magnitude of phenotypic coefficient of variation (PCV) and genotypic coefficient of variation (GCV) was recorded for grain yield per meter and effective tillers per meter and grain filling duration under timely and for grain yield per meter and effective tillers per meter under late sown condition. Above mentioned traits also showed high heritability coupled with high genetic advance in both the environments. Grain yield showed positive and significant correlation with effective tillers per meter, canopy temperature, but correlated negatively and significantly with plant height under timely sown condition. Under late sown condition grain yield showed positive and significant correlation with days to anthesis, plant height, effective tillers per meter, canopy temperature and grain weight. Path analysis showed that effective tillers per meter had highest positive direct on seed yield followed by days to anthesis, grain weight under both the environments, indicating that these were main contributors to grain yield.

\section{Introduction}

Wheat (Triticum aestivum L. em. Thell) is a self-pollinated crop of the member of Poaceae family and one of the most leading cereals of many countries of the world including India. It has been described as "King of cereals" because of the acreage it occupies, high productivity and the prominent position it holds in the international food grain trade. Wheat is consumed in a variety of way such as bread, chapatti, porridge, flour, juice etc. wheat has relatively high content of niacin and thiamin which are principally concerned in providing the special protein called 'Gluten' (Bhushan et al., 2013). India is the third largest wheat producer in the world
(FAO, 2015). Its total area is $30.23 \mathrm{mha}$, production $93.50 \mathrm{mt}$ and productivity 30.93 q/ha. Haryana with11.36 mt production, 2.57 mha area and 4.40 t/ha productivity ranks third in the country (Anonymous, 2016). It contributes food to $36 \%$ of the global population and $20 \%$ of the calories. The growing pace of population is declining the cultivated land which is a great concern for world's food security. With the passage of time this problem will be intensified further demanding increased cereal production to 1.7 fold to meet future challenges of food security (Mba et al., 2012). Developing countries produce and utilize $81 \%$ of wheat they 
consume. In the period leading up to 2020, demand for wheat for human consumption in developing countries is expected to grow at $1.6 \%$ each year. The global average wheat yield must be increase during the coming 25 years from 2.6 to 3.5 tones ha ${ }^{-1}$ (Amirjani, 2012). Hence, there is a need to raise the wheat productivity.

Wheat production is affected by several environmental factors responsible for yield losses over world including India. Environmental stresses affect negatively plant growth, productivity, reproductive capacity, and survival. Environmental stress may result from abiotic factors and biotic factors.

Among abiotic factors heat stress is a major production constraint for bread wheat grown in non-temperate environments (Mason et al., 2010; Pinto et al., 2010). High temperature is affecting about 65 to $70 \mathrm{mha}$ in the World (Reynolds et al., 1994), around 13.5 mha area in India (Joshi et al., 2007).

The influence of high temperatures on growth and development of wheat and other crops is well documented (Wheeler, et al., 2000). Heat decreases leaf photosynthetic rate, increase embryo abortion, lesser grain number, and decrease filling duration of grains resulting in lower grain yield (Prasad et al., 2006). When experienced during the reproductive phase, high temperatures induce the loss of both grain weight and number (Hays et al., 2007).

In order to raise the yield potential of the crop, genetic variability in the existing wheat germplasm needs to be utilized in the breeding programme. Thus, there is an urgent need to study the variability of the crop.

The assessment of genetic parameters like genotypic variability, phenotypic variability, genotypic coefficient of variation, phenotypic coefficient of variation, heritability and genetic advance are significant for the effective selection and improvement of breeding population. The genetic tools such as correlation and path analysis are useful in resolving complex polygenetic control of yield trait. The present study therefore was conducted to estimate magnitude of phenotypic and genotypic variability, heritability, genetic advance, correlation coefficient and path analysis with the aim to utilize the genetic information gained in developing superior wheat genotypes and varieties.

\section{Materials and Methods}

The experimental materials comprised of genetically diverse 60wheat genotypes which were raised under timely (E1) and late sown condition (E2) during Rabi season, 2016-17 in a randomized block design with three replications at research farm of Wheat Section, Department of Genetics and Plant Breeding, CCS Haryana Agricultural University, Hisar. The plot size was $3 \mathrm{mx}$ $0.40 \mathrm{~m}$ with row to row spacing of $20 \mathrm{~cm}$. Hisar is located in global geographical position between $29.09^{\circ} \mathrm{N}$ and $75.43^{\circ} \mathrm{E}$ in western Haryana. Observations for all the traits were recorded by taking five plants per plot. The data were recorded for days to heading, days to anthesis, days to maturity, plant height, effective tillers per meter, chlorophyll fluorescence, canopy temperature, grain yield per meter, grain weight, and grain filling duration. Analysis of variance for the observations recorded on different characters was carried out as per the standard procedure of Fisher (1930). Genotypic and phenotypic coefficients of variation were estimated according to Burton and Devane (1953). Heritability in broad sense and Genetic advance were worked out as per the procedures of Falconer (1981), Johnson et al., (1955), respectively. Phenotypic and genotypic correlation and path coefficients of 
variation were computed as per the method given by Dewey and Lu (1959).

\section{Results and Discussion}

\section{Analysis of variance}

The mean sum of squares for different traits under study has been presented in table 1 . The results indicated that mean sum of squares due to genotype were significant for all the morphological and physiological characters studied under both timely and late sown conditions indicating thereby the prevalence of enough genetic variability in the materials under study for selection and improvement. Therefore, further analysis of data is appropriate for computation of correlation coefficient analysis. Similar results were also recorded by Kumar et al., (2013) and Nukasani et al., (2013).

\section{Variability parameters}

The result of mean, range, genotypic coefficient of variation (GCV), Phenotypic Coefficient of Variation (PCV), heritability (broad sense), and expected genetic advance have been presented in table 2 . This revealed sufficient range of variation among genotypes for each character.

\section{GCV and PCV}

A perusal of table 3 revealed that phenotypic coefficients of variance (PCV) was higher than genotypic coefficients of variance (GCV) for all the characters under study but the difference was relatively small indicating that these characters were less influenced by the environment. Under timely sown condition Grain filling duration depicted moderate PCV and GCV, respectively followed by grain yield per meter and effective tiller per meter whereas, under late sown condition Grain yield per meter and effective tillers per meter showed moderate value of PCV and GCV.
Similar results were obtained by Bhushan et $a l$. , (2013) for grain yield and productive tiller per plant. Contrary to these results Gowda et al., (2011) reported high PCV and GCV for grain yield, canopy temperature depression (10 days after anthesis) and canopy temperature depression (at anthesis), by Veeresha and Naik (2016), Jan and Kashyap (2013) and by Nukasani et al., (2013) for number of productive tillers per meter and grain yield.

Lowest PCV and GCV were obtained for plant height followed by days to maturity, chlorophyll fluorescence, days to anthesis, days to heading and 1000-grain weight under timely sown condition and for days to maturity, days to anthesis, days to heading, chlorophyll fluorescence, plant height, grain filling duration, canopy temperature and 1000-grain weight under late sown condition. Similar results were reported by Bhushal and Sarial (2016) for days to heading, days to anthesis, days to physiological maturity and grain filling duration, by Bhushan et al., (2013) for days to heading, days to maturity and 1000-grain weight. Nukasani et al., (2013) reported moderate PCV and GCV for plant height and 1000-grain weight.

\section{Heritability and genetic advance}

The genetic parameter heritability determines the extent of genetic control of a given trait and its transmission to progeny and, hence has bearing on the selection efficiency of trait concerned. Johnson et al., (1955) advocated that for selection to be effective, heritability and genetic advance should be considered together. Under timely sown condition High estimates of heritability coupled with high genetic advance were recorded for effective tiller per meter (98.19 and 29.57), grain yield per meter (97.92 and 30.79) and grain filling duration (91.83 and 32.49) whereas, under late sown condition High estimates of heritability and genetic advance have been 
observed for effective tillers per meter (97.92 and 30.44) and grain yield per meter (97.11 and 39.43). The high heritability and genetic advance are attributed due to additive gene action with least environment influence which would result in effective selection for these traits. Similar results were also recorded by Nukasani et al., (2013) for tillers per meter and grain yield per meter, by Singh et al., (2012) for tillers per plot and grain yield and by Veeresha and Naik (2016) for number of productive tillers per meter and grain yield. Contrary to this Kumar et al., (2014) observed moderate heritability for number of tillers per meter and grain yield.

High heritability with moderate genetic advance was observed for 1000-grain weight (83.86 and 15.43) and canopy temperature (81.79 and 15.35) under timely sown condition and for High heritability and moderate genetic advance was observed for grain filling duration (84.73 and 12.14), canopy temperature (74.26 and 11.35), and 1000-grain weight (73.85 and 13.88) under late sown condition.

Similar results were also obtained by Jan and Kashyap (2013), Bhushan et al., (2013) and Kumar et al., (2014) for 1000-grain weight.

High heritability and low genetic advance was reported for days to heading (90.17 and 8.51), chlorophyll fluorescence (88.47 and 6.21), days to anthesis (88.39 and 8.12), days to maturity (85.61 and 4.31) and plant height (76.63 and 5.08) showed low genetic advance under timely sown condition and for plant height (91.71 and 8.51), chlorophyll fluorescence (87.89 and 6.69), days to anthesis (87.38 and 5.68), days to heading (87.04 and 5.67) and days to maturity (85.80 and 4.02) under late sown condition, indicating the presence of non-additive gene action hence, ineffective selection for the trait. Similar findings were obtained by Jan and Kashyap (2013) and Kumar et al., (2014) for days to maturity, by Singh et al., (2012) and Rehman et al., (2016) for days to heading.

\section{Correlation coefficient analysis}

Yield, a complex polygenic trait has a large number of other contributing component traits. Correlation analysis reveals the relationship of dependent variable yield with its independent variables, thus association of various traits would determine their relative significance to improve yield. The results of correlation coefficient at phenotypic and genotypic level among different traits were studied and have been presented in table 3 (Timely sown) and table 4 (Late sown). In almost all the characters the magnitude of genotypic correlation coefficients was found higher than phenotypic correlation coefficients, thus indicating a good extent of strong inherent association between different characters.

Grain yield showed positive and significant correlation with effective tillers per meter, canopy temperature, but correlated negatively and significantly with plant height under timely sown condition. Under late sown condition grain yield showed positive and significant correlation with days to anthesis, plant height, effective tillers per meter, canopy temperature and grain weight. Similar results were reported by Nukasani et al., (2013) for tillers per meter and grain weight per spike, by Arya et al., (2005) for effective tillers per plant and by Singh et al., (2013) for test grain weight. Days to heading had positive and significant phenotypic correlation with days to anthesis, days to maturity, plant height under both the conditions. Effective tillers per meters showed positive and significant association with canopy temperature under timely sown condition but a negative and significant correlation under late sown condition. 
Table.1 Analysis of variance for various characters in 60 wheat genotypes under timely sown (E1) and late sown (E2) conditions

\begin{tabular}{|c|c|c|c|c|c|c|c|c|c|c|c|c|}
\hline & & & $\begin{array}{l}\text { Days to } \\
\text { heading }\end{array}$ & $\begin{array}{l}\text { Days to } \\
\text { anthesis }\end{array}$ & $\begin{array}{l}\text { Days to } \\
\text { maturity }\end{array}$ & $\begin{array}{l}\text { Plant } \\
\text { height }\end{array}$ & $\begin{array}{l}\text { Effective } \\
\text { tillers per } \\
\text { meter }\end{array}$ & $\begin{array}{l}\text { Chlorophyll } \\
\text { fluorescence }\end{array}$ & $\begin{array}{l}\text { Canopy } \\
\text { temperature }\end{array}$ & $\begin{array}{l}\text { Grain yield } \\
\text { per meter }\end{array}$ & $\begin{array}{l}\text { 1000- } \\
\text { Grain } \\
\text { weight }\end{array}$ & $\begin{array}{l}\text { Grain } \\
\text { filling } \\
\text { duration }\end{array}$ \\
\hline \multirow{2}{*}{ Replication } & \multirow{2}{*}{2} & E1 & 0.02 & 4.02 & 2.92 & 33.42 & 6.44 & 0.00 & 0.53 & 62.74 & 0.91 & 2.71 \\
\hline & & E2 & 2.84 & 10.34 & 2.10 & 38.79 & 10.34 & 0.00 & 1.19 & 226.10 & 0.6 & 5.49 \\
\hline \multirow{2}{*}{ Treatment } & \multirow{2}{*}{59} & E1 & $48.02 * *$ & $49.83 * *$ & $31.87 * *$ & $30.37 * *$ & $864.06^{* *}$ & $0.002 * *$ & $15.05 * *$ & $1,016.50 * *$ & $40.24 * *$ & $91.80 * *$ \\
\hline & & E2 & $17.98 * *$ & $20.05 * *$ & $20.50 * *$ & $57.61 * *$ & $333.92 * *$ & $0.00 * *$ & $10.84 * *$ & $452.18^{* *}$ & $32.58 * *$ & $13.32 * *$ \\
\hline \multirow{2}{*}{ Error } & \multirow{2}{*}{118} & E1 & 1.68 & 2.09 & 1.69 & 2.80 & 5.28 & 0.00 & 1.04 & 7.85 & 2.43 & 2.64 \\
\hline & & E2 & 0.85 & 0.92 & 1.07 & 1.68 & 2.35 & 0.00 & 1.12 & 4.43 & 3.44 & 0.75 \\
\hline
\end{tabular}

Table.2 Genetic parameters for yield and its component traits in wheat under timely (E1) and late sown (E2) condition

\begin{tabular}{|l|l|l|l|l|l|l|l|l|l|l|}
\hline Characters & \multicolumn{3}{|c|}{ Mean } & \multicolumn{3}{c|}{ GCV $(\%)$} & \multicolumn{3}{c|}{ PCV $(\%)$} & \multicolumn{3}{c|}{ h$^{2}($ bs $)$} \\
\hline & E1 & E2 & E1 & E2 & E1 & E2 & E1 & E2 & E1 & E2 \\
\hline DH & 90.30 & 81.03 & 4.352 & 2.95 & 4.58 & 3.16 & 90.17 & 87.04 & 8.51 & 4.59 \\
\hline DA & 95.12 & 85.66 & 4.19 & 2.95 & 4.46 & 3.15 & 88.39 & 87.38 & 8.12 & 4.86 \\
\hline DM & 140.25 & 120.7 & 2.24 & 2.1 & 2.44 & 2.27 & 85.61 & 85.8 & 4.31 & 4.86 \\
\hline PH & 107.53 & 100.1 & 2.82 & 4.32 & 3.22 & 4.5 & 76.63 & 91.71 & 5.08 & 8.52 \\
\hline ET & 116.79 & 70.41 & 14.49 & 14.93 & 14.62 & 15.09 & 98.19 & 97.92 & 29.57 & 21.43 \\
\hline CFL & 0.71 & 0.66 & 3.21 & 3.46 & 3.41 & 3.69 & 88.47 & 87.89 & 6.21 & 0.04 \\
\hline CT & 26.23 & 28.15 & 8.24 & 6.39 & 9.11 & 7.42 & 81.79 & 74.26 & 15.35 & 3.19 \\
\hline GY & 121.24 & 62.9 & 15.12 & 19.42 & 15.3 & 19.71 & 97.72 & 97.11 & 30.79 & 24.8 \\
\hline GW & 43.41 & 39.76 & 8.18 & 7.84 & 8.93 & 9.12 & 83.86 & 73.85 & 15.43 & 5.52 \\
\hline GFD & 33.12 & 31.96 & 16.46 & 6.4 & 17.17 & 6.95 & 91.83 & 84.73 & 32.49 & 3.88 \\
\hline
\end{tabular}


Table.3 Phenotypic (above Diagonal) and genotypic correlation coefficient (below diagonal) for Various characters in wheat genotypes under timely sown condition (E1)

\begin{tabular}{|c|c|c|c|c|c|c|c|c|c|c|}
\hline Traits & DH & DA & DM & $\mathbf{P H}$ & ET & CFL & CT & GY & GW & GFD \\
\hline DH & 1.000 & $0.985^{*}$ & $0.363^{*}$ & $0.605^{*}$ & 0.084 & $0.162^{*}$ & 0.123 & 0.100 & $-0.239^{*}$ & -0.018 \\
\hline DA & 0.995 & 1.000 & $0.354^{*}$ & 0.591 & 0.072 & $0.163^{*}$ & 0.104 & 0.084 & $-0.264^{*}$ & 0.002 \\
\hline DM & $0.401^{* * *}$ & $0.394^{* * *}$ & 1.000 & $0.502^{* * *}$ & -0.124 & 0.066 & -0.030 & -0.080 & $0.160^{*}$ & $0.408^{* * *}$ \\
\hline PH & $0.687^{* * *}$ & $0.673^{* * *}$ & $0.582^{* * *}$ & 1.000 & $-0.222^{* *}$ & $0.182^{*}$ & -0.064 & $-0.180^{*}$ & 0.022 & 0.125 \\
\hline ET & 0.084 & 0.072 & -0.139 & $-0.258^{2}$ & 1.000 & 0.088 & $0.274^{\text {*** }}$ & $0.940^{* * *}$ & 0.048 & 0.031 \\
\hline CFL & 0.165 & 0.169 & 0.081 & $0.239^{*}$ & 0.101 & 1.000 & 0.158 & 0.093 & -0.017 & 0.075 \\
\hline CT & 0.162 & 0.135 & -0.050 & -0.069 & 0.308 & 0.189 & 1.000 & $0.295^{*}$ & -0.052 & $-0.363^{*}$ \\
\hline GY & 0.115 & 0.102 & -0.092 & $-0.205^{* *}$ & $0.960^{* *}$ & 0.113 & $0.328^{* * *}$ & 1.000 & 0.099 & -0.011 \\
\hline $\mathbf{G W}$ & -0.270 & -0.304 & 0.195 & 0.007 & 0.051 & -0.020 & -0.036 & 0.101 & 1.000 & -0.044 \\
\hline GFD & -0.014 & 0.018 & $0.431^{*}$ & 0.175 & 0.029 & 0.076 & -0.419 & -0.011 & -0.028 & 1.000 \\
\hline
\end{tabular}

Table.4 Phenotypic (above Diagonal) and genotypic correlation coefficient (below diagonal) for Various characters in wheat genotypes under late sown condition (E2)

\begin{tabular}{|c|c|c|c|c|c|c|c|c|c|c|}
\hline Traits & DH & DA & DM & PH & ET & CFL & CT & GY & GW & GFD \\
\hline DH & 1.000 & $0.955^{* *}$ & $0.584^{* *}$ & $0.563^{* * *}$ & $0.189^{*}$ & 0.028 & 0.038 & $0.245^{* *}$ & $-0.149^{*}$ & 0.042 \\
\hline DA & 0.980 & 1.000 & $0.593^{*}$ & $0.581^{*}$ & $0.181^{*}$ & 0.030 & 0.050 & 0.237 & -0.153 & 0.027 \\
\hline DM & 0.615 & 0.626 & 1.000 & 0.373 & -0.059 & 0.107 & 0.083 & -0.042 & -0.233 & -0.045 \\
\hline $\mathbf{P H}$ & 0.611 & 0.622 & 0.404 & 1.000 & 0.144 & 0.149 & 0.095 & 0.155 & -0.101 & -0.069 \\
\hline ET & 0.209 & $0.203^{*}$ & -0.069 & 0.163 & 1.000 & -0.005 & -0.223 & 0.935 & 0.256 & -0.009 \\
\hline CFL & 0.043 & 0.047 & 0.124 & $0.169^{*}$ & -0.016 & 1.000 & 0.110 & 0.025 & -0.045 & 0.011 \\
\hline CT & 0.021 & 0.042 & 0.112 & 0.106 & $-0.265^{* * *}$ & 0.126 & 1.000 & $0.210^{* *}$ & $-0.231^{* *}$ & 0.057 \\
\hline GY & 0.266 & $0.255^{*}$ & -0.049 & 0.155 & 0.959 & 0.030 & $0.274^{*}$ & 1.000 & 0.237 & 0.070 \\
\hline GW & -0.214 & -0.232 & $-0.311^{2}$ & -0.131 & $0.298^{* * *}$ & -0.039 & $-0.310^{*}$ & 0.280 & 1.000 & 0.024 \\
\hline GFD & 0.036 & 0.033 & -0.086 & -0.068 & -0.015 & 0.028 & 0.102 & 0.082 & 0.016 & 1.000 \\
\hline
\end{tabular}

DH-Days to Heading, DA-Days to anthesis, DM-Days to maturity, PH-Plant height, ET-Effective tillers per meter, CFL-Chlorophyll fluorescence, CT-Canopy temperature, GYGrain yield per meter, GW-Grain weight, GFD-Grain filling duration. 
Table.5 Direct (diagonal) and indirect path effects of different characters on grain yield per meter in timely sown condition (E1)

\begin{tabular}{|c|c|c|c|c|c|c|c|c|c|}
\hline Trait & DH & DA & DM & $\mathbf{P H}$ & ET & CFL & CT & GW & GFD \\
\hline DH & -0.49006 & -0.4878 & -0.1964 & -0.33663 & -0.04138 & -0.08101 & -0.07958 & 0.13234 & 0.00682 \\
\hline $\mathbf{D A}$ & 0.48813 & 0.49039 & 0.19315 & 0.33009 & 0.0354 & 0.08281 & 0.06634 & -0.14923 & 0.00865 \\
\hline$\overline{D M}$ & 0.0169 & 0.01661 & 0.04218 & 0.02457 & -0.00587 & 0.0034 & -0.00212 & 0.00822 & 0.0182 \\
\hline $\mathbf{P H}$ & 0.02904 & 0.02845 & 0.02462 & 0.04227 & -0.01092 & 0.01009 & -0.00292 & 0.00031 & 0.0074 \\
\hline ET & 0.08239 & 0.07044 & -0.13573 & -0.25217 & 0.97586 & 0.09836 & 0.30028 & 0.04976 & 0.02812 \\
\hline CFL & 0.00039 & 0.0004 & 0.00019 & 0.00056 & 0.00024 & $\mathbf{0 . 0 0 2 3 5}$ & 0.00044 & -0.00005 & 0.00018 \\
\hline CT & 0.00292 & 0.00243 & -0.00091 & -0.00124 & 0.00554 & 0.0034 & 0.01799 & -0.00065 & -0.00754 \\
\hline GW & -0.01584 & -0.01785 & 0.01143 & 0.00043 & 0.00299 & -0.00119 & -0.00211 & 0.05865 & -0.00166 \\
\hline GFD & 0.00099 & -0.00125 & -0.03056 & -0.0124 & -0.00204 & -0.00537 & 0.02967 & 0.002 & -0.07082 \\
\hline GY (rg) & 0.115 & 0.102 & -0.092 & $-0.205^{* *}$ & $0.960^{* * *}$ & 0.113 & $0.328^{* * *}$ & 0.101 & -0.011 \\
\hline
\end{tabular}

Residual - 0.06937

Table.6 Direct (diagonal) and indirect path effects of different characters on grain yield per meter in late sown condition (E2)

\begin{tabular}{|c|c|c|c|c|c|c|c|c|c|}
\hline Trait & DH & DA & DM & $\mathbf{P H}$ & ET & CFL & CT & GW & GFD \\
\hline DH & -0.19964 & -0.20118 & -0.12288 & -0.12188 & -0.04174 & -0.00866 & -0.0041 & 0.04268 & -0.00719 \\
\hline $\mathbf{D A}$ & 0.32652 & 0.32403 & 0.20283 & 0.20145 & 0.06564 & 0.01523 & 0.01351 & -0.07533 & 0.01079 \\
\hline DM & -0.02043 & -0.02078 & -0.03319 & -0.0134 & 0.00228 & -0.00411 & -0.00372 & 0.01033 & 0.00286 \\
\hline $\mathbf{P H}$ & -0.03912 & -0.03984 & -0.02588 & -0.06408 & -0.01046 & -0.01083 & -0.00682 & 0.00842 & 0.00434 \\
\hline ET & 0.19618 & 0.1901 & -0.06439 & 0.15311 & $\mathbf{0 . 9 3 8 3 7}$ & -0.0149 & 0.24839 & 0.27929 & -0.01445 \\
\hline CFL & 0.00231 & 0.0025 & 0.00659 & 0.009 & -0.00085 & 0.05324 & 0.00669 & -0.00208 & 0.00148 \\
\hline CT & -0.00032 & -0.00064 & -0.00172 & -0.00163 & 0.00406 & -0.00193 & 0.01534 & 0.00476 & -0.00157 \\
\hline GW & -0.0023 & -0.00251 & -0.00335 & -0.00142 & 0.00321 & -0.00042 & -0.00334 & 0.01078 & 0.00017 \\
\hline GFD & 0.00307 & 0.00284 & -0.00735 & -0.00576 & -0.00131 & 0.00237 & 0.00871 & 0.00138 & 0.08519 \\
\hline GY (rg) & 0.266 & 0.255 & $-0.049^{\mathrm{NS}}$ & 0.155 & 0.959 & $0.030^{\mathrm{NS}}$ & 0.274 & 0.280 & $0.082^{\mathrm{N}}$ \\
\hline
\end{tabular}

Residual - 0.06346

DH-Days to Heading, DA-Days to anthesis, DM-Days to maturity, PH-Plant height, ET-Effective tillers per meter, CFL-Chlorophyll fluorescence, CT-Canopy temperature, GY-Grain yield per meter, GW-Grain weight, GFD-Grain filling duration. 
Canopy temperature showed positive and significant association with chlorophyll fluorescence under timely sown condition but under late sown condition the correlation was non-significant.

\section{Path coefficient analysis}

Since correlation studies alone are not sufficient to make picture of association analysis very clear, hence the assessment of real contribution of an individual character towards seed yield per plant becomes essential. Path coefficient provides a clear and more realistic picture of a complex situation that exists at correlation level. It measures the direct as well as indirect effect of one variable on the dependent variable through the other traits. The path coefficient analysis was done on genotypic correlations and results have been presented in table 5 (Timely sown) and table 6 (Late sown).

A critical perusal of path coefficient analysis in which diagonal values is direct effects revealed that effective tillers per meter had highest positive direct effect on seed yield followed by days to anthesis, grain weight, plant height, days to maturity, canopy temperature and chlorophyll fluorescence under timely sown condition. Under late sown condition effective tillers per meter had a highest positive direct effect on seed yield followed by days to anthesis, grain filling duration, chlorophyll fluorescence, canopy temperature and grain weight. Similar finding were also reported by Nukasani et al., (2013) for tillers per meter and grain weight per spike, by Bhushan et al., (2013) for productive tillers per plant and test weight. The negative direct effect was recorded for days to heading and grain filling duration under timely sown condition and for days to heading, plant height and days to maturity under late sown condition. Similar results were also obtained by Bhushan et al., (2013) for days to heading, days to maturity and grain filling period. Contrary to these results Nukasani et al., (2013) reported negative direct effect on grain yield although the magnitudes are very small. Residual factor value was found 0.06937 and 0.06346 under timely and late sown condition respectively indicated that there are some other factors influencing the grain yield, which were not being included in the study. From the results obtained in the present study, it can be concluded that effective tillers per meter and canopy temperature, in order, were the most important traits supporting grain yield in wheat. Therefore, more emphasis should be given on these traits while making selection for high yielding genotypes in wheat.

\section{References}

Anonymous 2016. Progress Report of All India Coordinated Wheat and Barley Improvement Project 2015-16, Director's Report. Ed. G.P. Singh, ICAR-Indian Institute of Wheat and Barley Research, Karnal, India. P96.

Amirjani, M. 2012. Estimation of wheat responses to "high" heat stress. American-Eurasian J. Sustain. Agric., 6: 222-233.

Arya, V.D., Panwar, I.S. and Lamba, R.A.S. 2005.Genetic variability, correlation and path analysis for yield and quality traits in bread wheat. Haryana agric. Uni. J. Res., 35:59-63.

Bhushan, B., Bharti, S., Ojha, A., Pandey, M., Singh, S., Gourav, Tayagi, B.S. and Singh, G. 2013. Genetic variability, correlation coefficient and path analysis of some quantitative traits in bread wheat. J. Wheat Res., 5:21-26.

Burton, G.W. and DeVane, E.W. 1953. Estimating heritability in tall Fescue (Festuca arundinacea) from replicated clonal material. Agron. J., 45:478-81.

Dewey, D.R. and Lu, H.K. 1959.A correlation 
and path analysis of components of crested wheat grass and seed production. Agron. J. 51: 515-518.

Falconer, D.S. 1981.Introduction to Quantitative Genetics, 2nd edn. Oliver and Boyd, Edinburg, London, UK, $316 \mathrm{p}$.

FAO, 2015.FAOSTAT.Food and Agriculture Organization of the United Nations. (http://faostat.fao.org).

Fisher, R. 1930. The agreement of field experiment. J. Mini. Agric. Great Britain, 33: 503-513.

Gowda, D.S.S., Singh, G.P. and Singh, A.M. 2011. Relationship between canopy temperature depression, membrane stability, relative water content and grain yield in bread wheat (Triticum aestivum) under heat-stress environments. Indian J. Agric. Sci. 81: 197-202.

Hays, D., Mason,E., Hwa, Do J., Menz, M. and Reynolds, M. 200. Expression quantitative trait loci mapping heat tolerance during reproductive development in wheat ( $T$. aestivum). In: Buck HT, Nisi JE, Salomo'n N (eds) Wheat production in stressed environments. Springer, Amsterdam, pp 373-382.

Jan, N. andKashyap, S. C. 2013.Studies on genetic variability in wheat (Triticum aestivum L. EmThell) under temperate conditions of Kashmir. Inter. J.Scie. Res., 5: 1442-1445.

Johansan, H.W., Robinson, H.F. and Comstock, R.E. 1955. Estimate of genetic and environmental variability in soybean. Agron. J., 47: 314-318.

Joshi, A.K., Ferrara, O., Crossa, J., Singh,G., Sharma, R., Chand, R. and Parsad, R. 2007. Combining superior agronomic performance and terminal heat tolerance with resistance to spot blotch (Bipolaris sorokiniana) in the warm humid Gangetic Plains of South Asia. Field
Crops Res. 103:53-61.

Kumar, V., Sharma, P.K., Kumar, H. and Gupta, V. 2014. Studies of variability and association of yield with some agromophological characters in bread wheat (Triticum aestivum L.). Indian J. Agric. Res., 48: 429-436.

Mason, R.E., Mondal, S., Beecher, F.W., Pacheco, A., Jampala, B., Ibrahim, A.M.H. and Hays, D.B. 2010. QTL associated with heat susceptibility index in wheat (Triticum aestivum L.) under short-term reproductive stage heat stress. Euphytica, 174: 423-436.

Mba, C., Guimaraes, E.P. and Ghosh, K. 2012. Re-orienting crop improvement for the changing climatic conditions of the 21st century. Agric. Food Secur., $1: 7$

Nukasani, V., Potdukhe, N.R., Bharad, S., Deshmukh, S., Shinde, S.M. 2013. Genetic variability, correlation and path analsysis in wheat. J. Wheat Res., 5:4851.

Pinto, R.S., Reynolds, M.P., McIntyre, C.L., Olivares-Villegas, J.J., Chapman, S.C. 2010. Heat and drought QTL in a wheat population designed to minimize confounding agronomic effects. Theor. Appl. Genet. 121:1001-1021.

Prasad, P.V.V., Boote, K.J. andAllen, L.H. 2006. Adverse high temperature effects on pollen viability, seed-set, seed yield and harvest index of grain-sorghum [Sorghum bicolor (L.) Moench] are more severe at elevated carbon dioxide due to higher tissue temperatures. Agr. Forest Meteorol, 139: 237-251.

Rehman, S.U., Abid, M.A., Bilal, M., Ashraf, J., Liaqat, S., Ahmed, R.I and Qanmber, G. 2015. Genotype by trait analysis and estimates of heritability of wheat (Triticum aestivum L.) under drought and control conditions. Basic Res. J. Agric. Sci. Rev., 4:127-134.

Reynolds, M.P., Balota, M., Delgado, M.I.B., 
Amani, J., Fischer, R.A. 1994. Physiological and morphological traits associated with spring wheat yield under hot, irrigated conditions. Aust. J. Plant Physiol., 21:717-730.

Singh, G., Tyagi, B. S., Singh, M. K., Bind, D., Saharan, M. S., Verma, A. and Sharma, I. 2012.Genetic analysis for economic traits in elite indigenous and exotic lines of bread wheat (Triticum aestivum L.) under timely sown high fertility conditions. J. Wheat Res., 4:45-
48.

Veeresha, B.A. and RudraNaik V., 2016.Analysis of genetic variability parameters for morpho-physiological, yield and quality traits under heat stress condition in bread wheat. Inter. J. Agric. Sci., 8:1119-1121.

Wheeler, T.R., Craufurd, P.Q., Ellis, R.H., Porter, J.R. and Vara Prasad, P.V. 2000.Temperature variability and the yield of annual crops. Agr, Ecosyst. Environ., 82: 159-167.

\section{How to cite this article:}

Neeru, I.S. Panwar and Vikram Singh. 2017. Genetic Parameters of Variability and Path Analysis in Wheat under Timely and Late Sown Conditions. Int.J.Curr.Microbiol.App.Sci. 6(7): 1914-1923. doi: https://doi.org/10.20546/ijcmas.2017.607.228 